\title{
A Preliminary Assessment of Coastal Vulnerability For Ngazidja Island, Comoros Archipelago, Western Indian Ocean
}

\section{Avouca Mahamoud ( $\sim$ mahamoudavouca@gmail.com )}

University of Gabes Faculty of Sciences of Gabes: Universite de Gabes Faculte des Sciences de Gabes

\section{Maher Gzam}

UR Applied Hydro-sciences, Higher Institute of Water Sciences and Technics, University of Gabes

\section{Nadjim Ahmed Mohamed}

Faculty of Sciences and Technology, University of Comoros

\section{Soulé Hamidou Hamada}

Faculty of Sciences and Technology, University of Comoros

\section{Mabrouk Montacer}

University of Gabes Faculty of Sciences of Gabes: Universite de Gabes Faculte des Sciences de Gabes

\section{Research Article}

Keywords: Vulnerability, High risk, Beach, Low risk, Steep cliff, Ngazidja Island.

Posted Date: September 7th, 2021

DOl: https://doi.org/10.21203/rs.3.rs-238284/v1

License: (c) (i) This work is licensed under a Creative Commons Attribution 4.0 International License.

Read Full License

Version of Record: A version of this preprint was published at Environmental Earth Sciences on January 1st, 2022. See the published version at https://doi.org/10.1007/s12665-021-10136-4. 


\section{Abstract}

In previous studies, an emphasis on the particular vulnerability of small island states to future sea-level rise and the intensity of increasing storm surges has been discussed. This preliminary assessment develops a Coastal Vulnerability Index (CVI) along the $202 \mathrm{~km}$ long coastline of Ngazidja Island (formerly Grande Comore, Comoros Archipelago), using fieldwork, remote sensing, and geographic information system tools (GIS). The CVI considers five structural variables: (a) geology, (b) geomorphology, (c) topography, (d) shoreline change, and (e) shoreline exposure). It also considers three physical process variables: (f) relative sea-level rise, $(\mathrm{g})$ significant wave height, and (h) mean tide range). The land-use variable was added in this analysis to highlight the human asset exposure in the surrounding areas. Each variable was ranked based on local physical and hydrodynamic conditions and their vulnerability contribution to sea-level rise. The CVI was computed in 270 sections. According to the vulnerability index, approximately $57.5 \%$ of the coastline is under low and moderate vulnerability. High and very-high vulnerabilities refer specifically to beaches and shores with old volcanic lava flows located mainly in the northern, northeastern, and southeastern parts of the island, approximately $42.5 \%$ of the coastline. The lowest value of CVI is 9.2 on high, rocky cliffs and the highest value is 160 on beaches. This vulnerability partition along the coastline is consistent with in situ indicators of coastal erosion and flooding. In a sealevel rise context, it is of prime importance to integrate coastal vulnerability maps with planning and sustainable management of the coastal zone.

\section{Introduction}

Climate change has compounded problems of environmental degradation in coastal zone. The rate of sea-level rise is estimated at 8 to $16 \mathrm{~mm} / \mathrm{yr}$ in 2100, while its estimation was only $3.2+/-0.4 \mathrm{~mm} / \mathrm{yr}$ in the early 1990s (Cazenave et al. 2015). These increases will accentuate coastline recession, degradation of coastal ecosystems, and loss of material assets (Anderson et al. 2015). On the African coastline, habitats of approximately 16 million people will be inundated per year. In addition, 10 million people will be displaced, and with a $43 \mathrm{~cm}$ rise in sea level, the total cost of the damage could be $\$ 38$ billion/year by 2100 (Brown et al. 2011). In the vicinity of the Comorian archipelago, the mean rate of sea-level rise obtained from satellite altimetry measures was 4 mm/yr between 1992-2013 (Cazenave et al. 2015). According to the Comorian Ministry of Rural Development (2006), an estimated 10\% of the coastal population will require relocation by 2050. Climate models forecast have shown increased intensity of tropical cyclones and heavier rainfall (Walsh et al. 2016). The Indian Ocean Basin registers about $10 \%$ of global cyclonic activity (Meetoo 2014). In addition, the Malherbe et al. study (2013) indicates an increase in rainfall in the basin subzone, between northern Mozambique and southern Tanzania, for the latter part of the $21^{\text {st }}$ century. This increase further emphasizes the potential coastal inundation risk. About forty tropical low-pressure systems were registered at the archipelago level between 1910 and 1990 (Legoff 2011). According to the Foreign Ministry report, the last intense cyclone was in 2019, cyclone Kenneth, which led to the displacement of 15,000 people, destroyed several hectares of plantations, and damaged electrical and telecommunications installations. Despite Madagascar being a natural barrier, the northern 
and southern parts of the archipelago in particular are exposed to rigorous waves from the eastern part of the Indian Ocean (tsunamis and tropical cyclonic waves). Furthermore, the rise in the temperature of oceanic water results in the dysfunction and loss of coastal marine ecosystems. In 2016, thermal anomalies caused coral bleaching of more than $60 \%$ of corals on the Great Barrier Reef (Hughes et al. 2018). Head et al. (2019) showed that $60 \%$ of coral cover of the Chagos Archipelago was affected in 2015. The coral reef ridges had enabled the dissipation of more than $80 \%$ of wave energy (Ferrario et al. 2014). The weakening of these natural barriers prevents their attenuation efficiency of coastal hazards such as coastal erosion and marine submersion.

Specific studies on coastal erosion and flooding, coral reef, morphological evolution of beaches, and cyclonic hazard effects highlight the coastal vulnerability (Legoff 2011; Sinane et al. 2011; Hauzer et al. 2013; Freed and Granek 2014; Ratter et al. 2016; Betzold and Mohamed 2017). In contrast, the concept of a Coastal Vulnerability Index ( $\mathrm{CVI}$ ) has been widely used to assess the level of physical vulnerability to sea-level rise. Different approaches are applied to compute the CVI values. However, the square root of product mean is among the most applied at all scales (local, national, and regional). For instance, it is used to assess the vulnerability to sea-level rise on the coasts of Gran Canaria in the Atlantic Ocean (Di Paola et al. 2018); Sagar and Bhola Islands in the Bay of Bengal (Islam et al. 2015; Jana 2020); Krk Island in the Adriatic Sea (Ružić et al. 2019); and Rangsang Island in Indonesia (Nurhuda et al. 2019). In addition, the square root of product mean has been tested on Australian, Canadian, Indian, Spanish, the Sultanate of Oman, and U.S. coastlines (Shaw et al. 1998; Abuodha and Woodroffe 2010; Arun Kumar and Kunte 2012; López Royo et al. 2016; Hereher et al. 2020). The results of these coastal assessments commonly indicate the very high vulnerability of shores with erodable substrate and low-lying coasts compared to rocky coast. These studies showed that the CVI method is easily adaptable to other coastal areas. Moreover, it significantly contributes as a planning tool for coastal management and protection. Small Island Developing States (SIDS) are considered more vulnerable to sea-level rise induced by climate change due to their limited territories characterized by low-lying coastal areas and limited coastal protection infrastructure. Littoral stability is strongly threatened by the occurrence of storms and flood risk. Therefore, this study assesses the coastal vulnerability of Ngazidja Island to the anticipated impacts of climate change using a CVI to develop a vulnerability map. Nine variables were adopted to perform the CVl: geology, geomorphology, topography, shoreline change, sea-level rise, significant height wave, mean tide range, shoreline exposure, and land-use. Particular attention is paid to the geology variable due to the lava flows heterogeneity in the coastal zone. Furthermore, the shoreline exposure and land-use are included to highlight the coral reef contribution to wave energy dissipation and the value of hinterland.

\section{Study area}

Geographically, Ngazidja Island lies between $11^{\circ} 20^{\prime} \mathrm{S}$ and $11^{\circ} 60^{\prime} \mathrm{S}$ latitudes and $43^{\circ} 10^{\prime} \mathrm{E}$ and $43^{\circ} 40^{\prime} \mathrm{E}$ longitudes at the northern entrance of the Mozambique channel in the western part of the Indian Ocean (Fig. 1). It is geologically the youngest island of the Comoros archipelago, approximately 10 million years old (Michon 2016). Ngazidja Island has numerous volcanic lava flows constituted by basalt rocks (aphyric, olivine, plagioclase-phyric, and alkali olivine basalts, basanites, ankaramites, oceanites, and 
hawaiites) (Bachèlery and Coudray 1993; Bachèlery et al. 2016). The island includes two high mountains, namely, Karthala $(2361 \mathrm{~m})$ in the centre and La Grille $(1069 \mathrm{~m})$ towards the north (Fig. 1b). The northern, northeastern, and southeastern shores include old lava flows, most of the coral beaches (few meters to approximately $2 \mathrm{~km}$ long) and coral reefs. The dune is less developed but it is more distinguishable on the upper beach of Hantsindzi. Low soft cliff is shaping in the front of old lava flows and alluvial plains of pyroclastic materials, particularly in Male and Ndroude. Coastal alluvial plains are used for agricultural purposes, essentially subsistence farming. Furthermore, these areas present an advantage of economic prospects such as seaside tourism and the hotel industry (e.g., the new hotel "Al camar Lodge"). However, they are exposed to wind-generated waves from the north and south directions, with the highest significant wave height of 2 to $3 \mathrm{~m}$ (Mahabot and Dev 2015). The northern and northeastern parts are exposed to storm surges and tsunamis from the eastern Indian Ocean, for instance, the 2019 Kenneth cyclone with a wind speed of $200 \mathrm{~km} / \mathrm{h}$ and the tsunami of 2004 . The rest of the coastline in mainly rocky consisting of recent lava flows of Karthala and La Grille volcanoes. In the western part, the coastline is cliffy with projecting rocks. Numerous rocky cliffs individualise this part of the coastline, of which the highest embodies the west flank, both cones of Ikoni (106 m) and Moindzaza-Amboini (124 m). Steep and long rocky cliffs with moderate heights (5-20 m) are present in Djomani, Domoni, Hahaya, and Mbachile shores. The center-western coastline experiences the lowest energy waves during the year. It is the most populous area, particularly from Ikoni to Itsandra-Mdjini, and includes the basic infrastructure, namely, the port, airport, power plant, and public hospital. In the eastern part, the coastline less presents projecting rocks. In austral winter, significant wave heights of $2 \mathrm{~m}$ with a low frequency reach this coast. Along the entire coastline, the tides are semi-diurnal with a mesotidal range, according to the French Navy's Hydrographic and Oceanographic Department (SHOM) data, and the spring tides can reach 3 to $4.9 \mathrm{~m}$ (Sinane et al. 2011).

\section{Material And Methods}

\section{Controlling variables}

The nine variables used in this study can be classified into three categories: 1 . Five structural variables of (a) geology, (b) geomorphology, (c) topography, (d) shoreline change, and (e) shoreline exposure; 2. Three physical process variables of ( $f$ ) relative sea-level rise, ( $g$ ) significant wave height, and (h) mean tide range; and 3. A socioeconomic factor (i) land-use. The data were obtained from various sources (fieldwork, maps, aerial photographs, satellite image, and bibliography; Table 1) and described in subsections below. Direct field surveys for collecting coastal geomorphology and land-use data were conducted along the entire coastline of Ngazidja. During low tide, we walked from 3 to $5 \mathrm{~h}$ to take measurements and geo-referencing (For example, cliffs) using a decametre and GPS. The classification of these variables was made while on the spot based on previous studies (For example, Mclaughlin and Cooper 2010; Nurhuda et al. 2019). The collected data was subsequently integrated into ArcGIS software and combined with high-resolution (1 dpi) aerial photographs.
(a) Geology 
This variable relates to the erodibility risk of bedrock that is subject daily to waves. Accordingly, unconsolidated rock is assigned to a high vulnerability (Shaw et al. 1998). Ngazidja Island volcanic rocks include aphyric, olivine, plagioclase-phyric, and alkali olivine basalts, basanites, ankaramites, oceanites, and hawaiites derived from Karthala and La Grille volcanoes lava flows (Fig. 2.a). The weathering degree allows distinguishing the older from the recent lava (Bachèlery and Coudray 1993; Bachèlery et al. 2016). For example, , recent lava flows of Karthala and La Grille indicate a high degree of weathering resistance compared to the older lava flows of Karthala and La Grille volcanoes which are more prone to weathering. The most indurated lava flows are recent, about $19^{\text {th }}$ and $20^{\text {th }}$ centuries, with little to no alteration in surface features. They indicate no habitation and a total absence of vegetation. The indurated lava flow has a conserved upper unit and a smoothed lower unit. The moderately indurated lava flow exhibits a preserved upper unit, or a little smoothed, while the lower unit is smoothed without significant weathering. The advanced weathered lava shows smoothed without obvious limits upper flows and erased flow limits of lower flows. The most weathered lava flow is smooth with ferralitic weathering. Their spatial distributions along the coastline are $34.8 \%, 38.8 \%, 16.3 \%, 15.5 \%$, and $2.9 \%$, respectively (Fig. 3a).

\section{(b) Geomorphology}

Most of the Ngazidja Island coastline comprises resistant basaltic rocks, beaches and unlithified rock cliffs (with an average of 2 to $3 \mathrm{~m}$ in height) which are the most vulnerable to wave actions. Although the unlithified rock cliff is active, it revealed no sign of a landslide. The most stable coastal landform is a high hard cliff (exceeding $10 \mathrm{~m}$ ) and is assigned to a rank value of 1 . A medium-hard sea cliff $(5-10 \mathrm{~m})$ can mitigate erosion effects, but it is sensitive to sea-level rise caused by cyclone and tsunami waves. Compared to the preceding one, the low rocky cliff is subject to inundation in the context of sea-level rise. Figure $3 \mathrm{~b}$ displays the coastal subdivision in terms of geomorphology. The high hard cliff occupies only $3.4 \%$ of the coastline. Medium-hard sea-cliff and low rocky cliffs are the most represented with $26.8 \%$ and $66 \%$ of the coastline, respectively. Unlithified rock cliff and beaches spatial distributions are $1 \%$ and $2.8 \%$ of the coastline, respectively.

(c) Topography

Coastal hazard assessment considers relief as a determining factor. A high risk is commonly associated with low-lying coastal areas (Hereher et al. 2020). The contour line of $100 \mathrm{~m}$ located $650 \mathrm{~m}$ from the shore is outside the sea influence. It is considered in this study as a reference to classify this variable (Table 1). The coastal topography is extracted from a Shuttle Radar Topography Mission (SRTM) on https://glovis.usgs.gov. The scene has a resolution of $30 \mathrm{~m}$, absolute horizontal and vertical accuracies of $20 \mathrm{~m}$ and $16 \mathrm{~m}$, respectively. The SRTM indicates that about $13 \%$ of the coastline is under the contour line of $10 \mathrm{~m} .73 \%$ and $11 \%$ of the coastline are located between 11 and $30 \mathrm{~m}$ and 31 and $50 \mathrm{~m}$, respectively (Fig. 3c). Only $2 \%$ of the coastline is above the contour line of $50 \mathrm{~m}$.

(d) Shoreline change 
The shoreline change study is performed over three decades. Shorelines (high-water mark) are extracted from Landsat TM1989 and OLI2019 scenes with 30 m resolutions in Idrisi SELVA software by the bandratioing method (Zhou et al. 2019). Shoreline change rates are computed using the End Point Rate method through the Digital Shoreline Analysis System tool of ArcGis. The results are accurate with a margin of error of $+/-0.1 \mathrm{~m} / \mathrm{yr}$ over the three decades. Most of the coastline (about $97.4 \%$ of the coastline) shows a retreat varying between 0 and $-1 \mathrm{~m} / \mathrm{yr}$. Some sedimentary accumulations $(2.1 \%$ of the coastline) display shoreline change rates between 0 and $+1 \mathrm{~m} / \mathrm{yr}$. The maximum advance is due to fillings made to extend the port of Moroni, which led to a shoreline change of +1 to $+4 \mathrm{~m} / \mathrm{yr}$ on a section presenting $0.5 \%$ of the shoreline (Fig. $4 \mathrm{a}$ ).

(e) Shoreline exposure

This variable was used in the Illawarra Coast to express the orientation of the shore relative to the wave direction (Abuodha and Woodroffe 2010). Shoreline exposure involves the main direction of the wave and the presence of promontory (e.g., coral reefs). This variable highlights the coral reef contribution to wave energy dissipation. Madagascar Island shelters the Comoros archipelago against severe waves from the East Indian Ocean. The southeast of Ngazidja Island also protected by the other three Comoros islands (Figs. $1 \mathrm{a}$ and $1 \mathrm{~b}$ ). Fringing coral reef edges about $60 \%$ of the coastline and it is being between 500 and 1500 metres in width. The important coral reef is situated in the northern part from Fassi to Ndroude and the southern part from Chindini to Male (Fig. 2a). Rigorous waves are associated with the dominant winds, in Kashkazi from the north and in Kusi from the south. According to these criteria, $28.2 \%$ of the coastline is sheltered. About $16.1 \%, 34.2 \%$, and $21.5 \%$ of the coastline is semi-exposed, exposed, and fully exposed, respectively (Fig. 4e).

(f) Relative sea-level rise

Previous studies indicate the significant contributions of sea-level rise to coastal ecosystem degradation and loss of material assets. Sea level data adopted here are from satellite altimetry measures in the period 1992 - 2013 (Cazenave et al. 2015). The mean rate of sea-level rise was $4 \mathrm{~mm} / \mathrm{yr}$ in the archipelago level. In this study, all the shoreline sections are assigned to a range of $4-5 \mathrm{~mm} / \mathrm{yr}$ (Fig. $4 \mathrm{f}$ ).

(g) Mean significant wave height

Ngazidja Island includes an entirely open wave-dominated coast. Wave height is related to the wind regime and tropical low-pressure system (Legoff 2011). In this study, wave height data was derived from measures realized offshore regions for austral summer and winter (Figs. 5a and 5b). Most frequent waves $(70 \%-80 \%)$ with heights between 2 and $3 \mathrm{~m}$ are from the south-southwest. During the austral summer, other rigorous waves are from the north-western part with frequencies below $10 \%$. Wave heights less than 2 m occur with low frequencies ( $<5 \%)$ in the East and West. Accordingly, about $42.2 \%$ of the coastline registers wave heights between 2 and $3 \mathrm{~m}$. Waves of 1 to $2 \mathrm{~m}$ and less than $1 \mathrm{~m}$ in height reach $38.7 \%$ and $19.1 \%$ of the coastline, respectively (Fig. $6 \mathrm{~g}$ ). 
(h) Mean tide range

This variable is widely discussed and shows different opinions according to the tidal regime. In a microtidal coastline $(<2 \mathrm{~m})$, shores with smaller tidal range are assumed sensitive (Thieler and HammarKlose 1999). In a macrotidal coastline ( $>4 \mathrm{~m}$ ), coastal hazards are specifically significant in the highest tidal levels (Khan and Chatterjee 2018). Ngazidja Island coastline is mesotidal (2-4 m) and semidiurnal. The tide is constant throughout the year and the same on the whole of the coast. Several witnesses assert that spring tides can contribute to coastal floods on some shores of the island. Figure $5 \mathrm{c}$ shows the mean water levels at low and high tide noted at the Moroni Port station between 1970 and 2019. Accordingly, the whole coastline is assigned to the tidal range of 3.1 to $4.9 \mathrm{~m}$ in this study (Table 1 and Fig. 6h).

(i) Land-use

Coastal vulnerability depends on both the intensity of the hazard and the hinterland nature. Land-use variable is ranked into five classes: bare rocks, grassy and shrubby formations, farm field, village, and city (Yin et al. 2012). The youngest lava flows include bare rocks that are uninhabited. Accordingly, this class is attributed to the rank value of 1 . Grassy and shrubby formations constitute the advanced stage with less weathered lava flows compared to the previous ones. The vulnerability increases with the farm fields' class. Agriculture is the principal sector of occupation for most of the population. Villages and cities are the most vulnerable due to human life and infrastructure. Figure 6i depicts the Ngazidja coastline in terms of the land-use variable displaying $11.4 \%$ as bare rocks (very low vulnerable), $52.4 \%$ as grassy and shrubby formations (low vulnerability), 21.4\% for farm fields (moderate vulnerability), 7.3\% for villages (high vulnerability), and $7.5 \%$ for cities (very high vulnerability).

\section{Data ranking and Coastal Vulnerability Index}

The coastline is subdivided into 270 sections by the superimposition of all variable maps. Juxtaposed sections are different by least one class, and the shortest and longest ones measure $30 \mathrm{~m}$ and $6 \mathrm{~km}$, respectively. The ranking of variables is based on local structural and hydrodynamic conditions. As in previous studies, degrees of vulnerability are ranked on a scale from 1 (very low) to 5 (very high; Table 1). The description of variables above indicates that all contribute equally to coastal vulnerability. Thus, the $\mathrm{CVI}$ is computed in this preliminary vulnerability assessment using the square root of the product of the ranked variables divided by the total number of variables (equation 1). This CVI formulation has the advantage of expanding the range of values (Shaw et al. 1998; Thieler and Hammar-Klose 2000; Hereher et al. 2020). Therefore, this formulation enables identifying the most determinant variables in coastal vulnerability. 


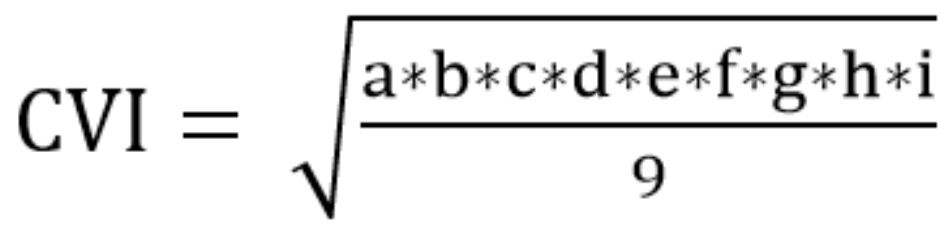

A vulnerability ranking of $\mathrm{CVI}$ scores is established according to statistical parameters. Low, moderate, high, and very high vulnerability are assigned to four statistical ranks: [Minimum- $1^{\text {st }}$ quartile], $]^{\text {st }}$ quartileAverage], ]Average-- ${ }^{\text {rd }}$ quartile], and $] 3^{\text {rd }}$ quartile-Maximum], respectively.

\section{Results And Discussion}

Overall coastal vulnerability

This assessment shows the first results of the vulnerability repartition on the Ngazidja coastline using a CVI vulnerability index. In situ witnesses of coastal erosion and flood are provided to highlight the contribution of variables in the vulnerability index ( $\mathrm{Ng}$ et al. 2019). According to the statistical ranking (Fig. 7), about $57.5 \%$ of the coastline displays low and moderate vulnerability. Low vulnerability class is the most represented with $34.3 \%$ of the coastline. Both low and moderate vulnerability shores are located mostly in the eastern and western parts of the island. High and very-high vulnerability coastal sections represent $18.2 \%$ and $24.3 \%$ of the coastline, respectively. These are shores commonly situated in the northern and southeastern parts. The lowest and highest values of CVI are 9.2 and 160 . The lowest value refers to the high rock cliffs of Ikoni and Moindzaza-Amboini located in the south of Moroni. They are the western flank of the volcanic cones formed by hyaloclastite rocks (Bachèlery and Coudray 1993). The low vulnerability of high rock cliff is also indicated in many other studies (Shaw et al. 1998; Abuodha and Woodroffe 2010). Furthermore, the coral reef that edges these cliffs can dissipate the wave energy (Ferrario et al. 2014). The highest value is noticed on the beach of Mitsamiouli. This result is consistent with the previous studies on the Gran Canaria coast, Spain. Las Canteras Beach shows the highest vulnerability with reducing beach width and sediment size (Di Paola et al. 2018). In addition to the narrowing of the beach width of Mitsamiouli, evident signs of coastal recession are present, in particular, on the northern part. A new seawall built in 2014 to protect a segment of National Road 1 is located a few meters from the shoreline. Other evidence, the south portion of the protective wall, which supposedly sheltered the largest market, collapsed in 2018 (Figs. 8a and 8b).

Structural variables

Ngazidja coastline mainly formed by consolidated basaltic rocks (aphyric, olivine, plagioclase-phyric, and alkali olivine basalts, basanites, ankaramites, oceanites, and hawaiites) from present and recent lava flows of La Grille and Karthala volcanoes (Bachèlery and Coudray 1993). This hard lithology is able to withstand the storm surges and mitigates coastal erosion. The highest vulnerability was found on old lava flows, whose upper units consist of highly weathered rock easily erodible. They are mainly alluvium of pyroclastic materials and volcanic slags (Figs. $8 \mathrm{c}$ and $8 \mathrm{~d}$ ). As is mentioned in the local and regional 
studies, the vulnerability increases from hard rocks (e.g., plutonic, volcanic rocks) to poorly and nonconsolidated materials. Ružić et al. (2019) highlighted the influence of the local geological fabric on the Krk Island coast, Croatia. Even in the presence of a beach, waves can erode the weathered rock mass. Such is the case of Ndroude shore in the northeastern part of Ngazidja Island. A low active cliff with alluvium of pyroclastic materials replaces the upper-beach (Figs. $8 \mathrm{~d}$ and $8 \mathrm{f}$ ). The same circumstances justify the very high vulnerability of the beaches located in the northern and southeastern parts of the island. Although it is considered as a good indicator of coastal vulnerability in many other studies (for instance, Pendleton et al. 2004; Sahana et al. 2019), shoreline change is not a determinant variable in this study. Both coastal geology and geomorphology seem to control the shoreline change, of which more than $95 \%$ of the coast indicates a shoreline retreat rate of less than $-1 \mathrm{~m} / \mathrm{yr}$ (Fig. $4 \mathrm{~d}$ ). With these low rates, this coastline is considered as stable (Thieler and Hammar-Klose 2000). Evident signs of coastal erosion are less discernible along the shoreline because of the geomorphological features of this island (resistant cliffs in the majority). However, coastal recession indicators such as erosion at the foot of seawall, active cliff formation and degradation of the bordering vegetation are found some shores, for example, on Mbachile, Ndroude and Male shores (Figs. 8c, 8d, 8e, and 8f). Similarly, sea-level rise has a low impact on this coast, where most localities are situated between 10 and $30 \mathrm{~m}$ above sea level (Hereher et al. 2020). Nevertheless, a sea-level rise caused by cyclone and tsunami waves is a significant threat of inhabitant shores located below $5 \mathrm{~m}$ (e.g., Bangoi-kouni shore). The shoreline exposure is the variable that least contributes to determining the coastal vulnerability. Coastal sections with large coral reefs (northeastern, northwestern, and southeastern parts) display a very high vulnerability. Wave breaking and bottom friction on the coral reef induce wave energy dissipation according to water depth. However, wave height and energy are less reduced on the shoreline during the high tide (Péquignet et al. 2011). The Comoros coastline experiences two daily high tides, of which the average annual water height is slightly above $4 \mathrm{~m}$ (Fig. 5c). With these tide heights, waves break near the shoreline. During the northwest monsoon, storm surge reaches the adjacent volcanic rocks. The lava flow of Singani is the most obvious example of the low contribution of shoreline exposure variable to coastal vulnerability. This lava flow was emitted in 1977 by the Karthala volcano (Bachèlery et al. 2016). Its coastal section shows a low vulnerability degree despite its full exposure (without coral reef) to rigorous waves from the south.

Physical process variables and land-use

In all previous studies, tide range vulnerability ranks refer to the tide regime (microtidal or macrotidal). According to the SHOM data, this study area includes a mesotidal regime (2-4 $\mathrm{m})$. Although the tide range is the same along the coastline, its impacts remain more significant on some low-lying shores. Such is the case of Bangoi-kouni shore in the extreme north of the island which is the most affected shore by coastal inundation. On August 12, 2018, the highest tide was $4.27 \mathrm{~m}$, and the wave run-up passes over the seawall. Nearly $11863 \mathrm{~m} 2$ of land was inundated for three hours with water heights of 40 $\mathrm{cm}$ within alleys and $1.5 \mathrm{~m}$ behind the seawall (Figs. $7 \mathrm{~g}$ and $7 \mathrm{~h}$ ). The increase in the sub-foundation height of houses $(>1 \mathrm{~m}$ ) testifies the residents' awareness. Thus, coastal risk related to the tide range in this study area is similar to macrotidal coastlines. The impact is more important in high tide (Shaw et al. 1998). Height wave variable is differently applied according to local hydrodynamic conditions. Ranks of 
mean, significant and maximum wave height and wave climate have been used on the Ivoirian, Krk Island, Canadian, and Spanish coasts, respectively (Shaw et al. 1998; Tano et al. 2016; López Royo et al. 2016; Ružić et al. 2019). In this study area, mean significant wave heights are the only current data available, and their impact increased according to the nature of the hinterland. The northern and southern parts are exposed to wind-generated waves (Kashkazi and Kusi) from the north and south directions, with a mean significant wave height of 2 to $3 \mathrm{~m}$ (Mahabot and Dev 2015). Bare ground, grassy and shrubby formations, and farm fields and beaches displayed low, moderate, and high to very high vulnerability, respectively. Socioeconomic factors include numerous variables such as land-use, population, cultural heritage, and conservation status (Mclaughlin and Cooper 2010; Yin et al. 2012). For the lack of accurate data, only the land-use variable is used in this preliminary study to highlight the hinterland value. The most urbanized coastal area (From Ikoni to Itsandra-Mdjini) is located in the western part, where the vulnerability is low to moderate. This part experiences fewer waves with low heights over the year, and the infrastructure and dwellings are primarily located more than $10 \mathrm{~m}$ above sea-level. Moreover, shoreline retreat is less significant, even during a tropical depression passage, such as the Kenneth Cyclone in 2019 (category 5). That is not the case for very-low elevated coastal areas with higher population density, for instance, on the Sagar Island in India with the Aila cyclone in 2009 (Turvey 2007; Jana 2020). By contrast, this variable displays the high vulnerability of the inhabited low-lying shores, of which the majority is protected by a seawall along more than $60 \%$ of their coastline. Betzold and Mohamed (2017) also reported using seawalls as a common way to prevent coastal erosion and flooding despite the fact that they are often poorly designed and constructed. The lack of accurate data (e.g., socioeconomic data) is among the limitations of this study. However, field surveys, remote sensing, and SIG allowed the mapping of the vulnerability distribution along the entire Ngazidja Island coastline. The study shows that the ranking of variables should be based on local geological and hydrodynamic conditions (Koroglu et al. 2019; Ružić et al. 2019). Thus, this first vulnerability assessment could be a helpful tool to propose coastal management solutions. For example, the relocation of the population in inhabited low-lying shores would attenuate the risk related to sea-level rise and storm surges (McLeman 2018).

\section{Conclusions}

The CVI is an efficient method to provide insight into coastal damage due to sea-level rise and storm surges. In addition to seven geological and physical process variables widely used in previous studies, land-use and shoreline exposure variables are added in this study to highlight coastal vulnerability more accurately. This preliminary assessment indicated that the eastern and western coastlines of Ngazidja Island are the least vulnerable. Northern, northeastern, and southeastern coastlines were identified as being extremely highly vulnerable. These parts include most of the beaches and shores with old volcanic lava. The study showed that geology, geomorphology, topography, wave height, and land-use are the most important variables that determine a CVI for Ngazidja Island to sea-level rise. In situ evidence of coastal erosion and flooding such as active cliffs, seawall construction, and vegetation degradation were determinant indicators of vulnerability partition reliability. However, the need to update data is paramount. All variables are closely related to physical, hydrodynamic, and socioeconomic changes. As with most 
SIDS, the numbers of tide and wave gauge stations and high-resolution data are limited. Also, this study highlights the lack of geological data, in particular, lithology and subsidence. However, this methodology will permit adding more accurate data as it become available. Despite these limitations, fieldwork, remote sensing, and GIS allow developing a local CVI that complies with field conditions. Moreover, this preliminary vulnerability assessment on Ngazidja Island coastline may facilitate future studies, such as the modeling study and development of maps of sea-level rise, coastal erosion, and marine submersion hazards. The information provided by this coastal vulnerability assessment is a significant contribution that could promote effective coastal planning on this island, where coastal management is still in its infancy. It will enable local coastal planners to have a broad overview of the relative vulnerability partition on the island scale for developing sustainable coastal management and development. Following the achieved results, we suggest applying this methodology to the rest of the Comorian islands.

\section{Declarations}

\section{Acknowledgements}

We would like to thank the three anonymous reviewers who provided very insightful comments and suggestions that greatly strengthened our manuscript. Also, we would like to show our gratitude to the Alliance Mondiale contre le Changement Climatique (AMCC) in the Comoros for providing their aerial photographs that have permitted us to have a general overview of coastal geomorphology and land-use.

\section{Funding}

No funding was received for conducting this study.

\section{References}

1. Abuodha PAO, Woodroffe CD (2010) Assessing Vulnerability to Sea level Rise Using a Coastal Sensitivity Index: A case study from Southeast Australia. J Coast Conserv 14(3):189-205. https://doi.org/10.1007/s11852-010-0097-0

2. Anderson TR, Fletcher $\mathrm{CH}$, Barbee MM, Frazer LN, Romine BM (2015) Doubling of Coastal Erosion under Rising Sea Level by Mid-Century in Hawaii. Nat Hazards 78(1):75-103. https://doi.org/10.1007/s11069-015-1698-6

3. Arun Kumar A, Kunte PD (2012) Coastal Vulnerability Assessment for Chennai, East Coast of India Using Geospatial Techniques. Nat Hazards 64(1):853-872. https://doi.org/10.1007/s11069-0120276-4

4. Bachèlery P, Coudray J (1993) Carte volcano-tectonique de la Grande Comore $(1: 50,000)$. Laboratoire de cartographie. CIRAD-CA, Montpellier. https://agritrop.cirad.fr/483016/

5. Bachèlery P, Morin J, Villeneuve N, Soulé H, Nassor H, Ali AR (2016) Structure and Eruptive History of Karthala Volcano. In: Bachelery P, Lenat JF, Di Muro A, Michon L (eds) Active Volcanoes of the 
Southwest Indian Ocean. Active Volcanoes of the World. Springer, Berlin, pp 345-366.

https://doi.org/10.1007/978-3-642-31395-0_22

6. Betzold C, Mohamed I (2017) Seawalls as a response to coastal erosion and flooding: a case study from Grande Comore, Comoros (West Indian Ocean). Reg Environ Changement 17(4):1077-1087

7. Brown S, Kebede AS, Nicholls RJ (2011) Sea level rise and impacts in Africa, 2000 to 2100 . School of Civil Engineering and the Environment University of Southampton, UK

8. Cazenave A, Berthier E, Meyssignac B, Le Cozannet G, Masson-Delmotte V, Salas y Melia D (2015) Sea level variations: past, present and future. Meteorologie 88:69-82. http://dx.doi.org/10.4267/2042/56363

9. Di Paola G, Aucelli PPC, Benassai G, Iglesias J, Rodríguez G, Rosskopf CM (2018) The assessment of the coastal vulnerability and exposure degree of Gran Canaria Island (Spain) with a focus on the coastal risk of Las Canteras Beach in Las Palmas de Gran Canaria. J Coast Conserv 22(5):10011015. https://doi.org/10.1007/s11852-017-0574-9

10. Ferrario F, Beck MW, Storlazzi CD, Micheli F, Shepard CC, Airoldi L (2014) The effectiveness of coral reefs for coastal hazard risk reduction and adaptation. Nat Commun 5(1):3794. https://doi.org/10.1038/ncomms4794

11. Freed S, Granek EF (2014) Effects of human activities on the World's most vulnerable coral reefs: Comoros case study. Coast Management 42:280-296. https://doi.org/10.1080/08920753.2014.904261

12. Hauzer M, Dearden P, Murray G (2013) The fisherwomen of Ngazidja Island, Comoros: fisheries livelihoods, impacts, and implications for management. Fish Res 140:28-35. https://doi.org/10.1016/j.fishres.2012.12.001

13. Head CEI, Bayley DTI, Rowlands G, Roche RC, Tickler DM, Rogers AD, Koldewey H, Turner JR, AndradiBrown DA (2019) Coral bleaching impacts from Back-to-Back 2015-2016 thermal anomalies in the remote central Indian Ocean. Coral Reefs 38(4):605-618. https://doi.org/10.1007/s00338-01901821-9

14. Hereher M, Al-Awadhi T, Al-Hatrushi S, Charabi Y, Mansour S, Al-Nasiri N, Sherief Y, El-Kenawy A (2020) Assessment of the coastal vulnerability to sea level rise: Sultanate of Oman. Environ Earth Sci 79(15):369. https://doi.org/10.1007/s12665-020-09113-0

15. Hughes TP, Kerry JT, Simpson T (2018) Large-scale bleaching of corals on the Great Barrier Reef. Ecology 99(2):501-501. https://doi.org/10.1002/ecy.2092

16. Islam MA, Hossain MS, Murshed S (2015) Assessment of coastal vulnerability due to sea level change at Bhola Island, Bangladesh: using geospatial techniques. J Indian Soc Remote Sens 43(3):625-637. https://doi.org/10.1007/s12524-014-0426-0

17. Jana S (2020) Micro-level coastal vulnerability assessment in relation to post-Aila landscape alteration at the fragile coastal stretch of the Sagar Island, India. Reg Stud Mar Sci 33:100908. https://doi.org/10.1016/j.rsma.2019.100908 
18. Khan A, Chatterjee S (2018) Quantification of Vulnerability: A Comprehensive Framework for the Bay of Bengal. Springer, Cham

19. Koroglu A, Ranasinghe R, Jiménez JA, Dastgheib A (2019) Comparison of Coastal Vulnerability Index Applications for Barcelona Province. Ocean Coast Manag 178:104799

20. Legoff N (2011) Les Comores et l'aléa cyclonique dans le contexte des changements climatiques: la vulnérabilité différenciée d'Anjouan et de Mayotte. Vertigo - la revue électronique en sciences de l'environnement 10(3):0-0. https://doi.org/10.4000/vertigo.10497

21. López Royo M, Ranasinghe R, Jiménez JA (2016) A Rapid, low-cost approach to coastal vulnerability assessment at a national level. J Coast Res 32(4):932-945

22. Mahabot M, Dev GP (2015) Rapport Final POCTOI UMR ESPACE DEV 20-30 Septembre 2014. 33 p

23. Malherbe J, Engelbrecht FA, Landman WA (2013) Projected changes in tropical cyclone climatology and landfall in the southwest Indian Ocean region under enhanced anthropogenic forcing. Clim Dyn 40(11):2867-2886. https://doi.org/10.1007/s00382-012-1635-2

24. Mclaughlin S, Cooper JAG (2010) A multi-scale coastal vulnerability index: a tool for coastal managers? Environ Hazards 9(3):233-248. https://doi.org/10.3763/ehaz.2010.0052

25. McLeman R (2018) Migration and displacement risks due to mean sea level rise. Bulletin of the Atomic Scientists 74(3):148-154. https://doi.org/10.1080/00963402.2018.1461951

26. Meetoo C (2014) Étude Des Conditions de Cyclogenèse Tropicale Sur Le Sud-Ouest de l'océan Indien. Dissertation, Université Toulouse III Paul Sabatier

27. Michon $L$ (2016) The Volcanism of the Comoros Archipelago Integrated at a Regional Scale. In: Bachelery P, Lenat JF, Di Muro A, Michon L (eds) Active Volcanoes of the Southwest Indian Ocean. Active Volcanoes of the World. Springer, Berlin, pp 333-344. https://doi.org/10.1007/978-3-64231395-0_21

28. Ministère du Développement Rural, de l'Artisanat et de l'Environnement (2006) Programme d'action National d'adaptation Aux Changements Climatiques (PANA)

29. Ng K, Borges P, Phillips MR, Medeiros A, Calado H (2019) An Integrated Coastal Vulnerability Approach to Small Islands: The Azores case. Sci Total Environ 690:1218-1227. https://doi.org/10.1016/j.scitotenv.2019.07.013

30. Nurhuda A, Mubarak M, Sutikno S (2019) Analysis of coastal vulnerability of Rangsang Island due to climate changes. J Degrade Min Land Manage 6:1907-1914. https://doi.org/10.15243/jdmlm.2019.064.1907

31. Pendleton EA, Williams SJ, Thieler ER (2004) Coastal vulnerability assessment of Assateague Island National Seashore (ASIS) to sea level rise. Open-file report $2004-1020$. US Department of the Interior, US Geological Survey

32. Péquignet AC, Becker JM, Merrifield MA, Boc SJ (2011) The dissipation of wind wave energy across a fringing reef at Ipan, Guam. Coral Reefs 30(1):71-82. https://doi.org/10.1007/s00338-011-0719-5 
33. Ratter BMW, Petzold J, Sinane K (2016) Considering the locals: coastal construction and destruction in times of climate change on Anjouan, Comoros. Nat Resour Forum 40:112-126

34. Ružić I, Dugonjić Jovančević S, Benac Č, Krvavica N (2019) Assessment of the coastal vulnerability index in an area of complex geological conditions on the Krk Island, Northeast Adriatic Sea. Geosciences 9(5):219. https://doi.org/10.3390/geosciences9050219

35. Sahana M, Hong H, Ahmed R, Patel PP, Bhakat P, Sajjad H (2019) Assessing coastal island vulnerability in the Sundarban Biosphere Reserve, India, using geospatial technology. Environ Earth Sci 78(10):304. https://doi.org/10.1007/s12665-019-8293-1

36. Shaw J, Taylor RB, Forbes DL, Ruz MH, Solomon S (1998) Sensitivity of the coasts of Canada to sea level rise. Ottawa, Canada

37. Sinane K, David G, Pennober G, Troadec R (2011) Fragilisation et modification des formations littorales meubles sur lîle d'Anjouan (Comores): Quand l'érosion d'origine anthropique se conjugue au Changement Climatique. VertigO-La Revue Électronique En Sciences de l'environnement 10:0-0

38. Tano RA, Aman A, Kouadio KY, Toualy E, Ali KE, Assamoi P (2016) Assessment of the Ivorian coastal vulnerability. J Coast Res 32(6):1495-1503

39. Thieler ER, Hammar-Klose ES (2000) National assessment of coastal vulnerability to sea level rise: preliminary results for the US. Pacific Coast, Open-file r 00-178, 1 sheet. US Geological Survey

40. Thieler ER, Hammar-Klose ES (1999) National assessment of coastal vulnerability to sea level rise, US Atlantic coast, Open-file report 99593, 1 sheet. US Geological Survey, Woods Hole

41. Turvey R (2007) Vulnerability assessment of developing countries: the case of Small-Island Developing States. Dev Policy Rev 25(2):243-264. https://doi.org/10.1111/j.14677679.2007.00368.x

42. Walsh KJE, McBride JL, Klotzbach PJ, Balachandran S, Camargo SJ, Holland G, Knutson TR et al (2016) Tropical Cyclones and Climate Change. Wiley Interdisciplinary Reviews: Climate Change 7(1):6589. https://doi.org/10.1002/wcc.371

43. Yin J, Yin Z, Wang J, Xu S (2012) National assessment of coastal vulnerability to sea level rise for the Chinese Coast. J Coast Conserv 16(1):123-133. https://doi.org/10.1007/s11852-012-0180-9

44. Zhou Y, He B, Xiao F, Feng Q, Kou J, Liu H (2019) Retrieving the lake trophic level index with Landsat8 Image by atmospheric parameter and RBF: a case study of lakes in Wuhan, China. Remote Sens 11(4):457. https://doi.org/10.3390/rs11040457

\section{Table}

Table 1 Vulnerability classes adopted for Ngazidja Island coastline and sources of data 


\begin{tabular}{|c|c|c|c|c|c|c|c|}
\hline Variable & Unit & Very-low (1) & Low (2) & Moderate (3) & High (4) & Very-high (5) & Sources of the data \\
\hline (a) & - & $\begin{array}{l}\text { Most indurate } \\
\text { lava flow and } \\
\text { hyaloclastites }\end{array}$ & $\begin{array}{l}\text { Indurate lava } \\
\text { flow }\end{array}$ & $\begin{array}{l}\text { Moderately } \\
\text { indurate lava } \\
\text { flow }\end{array}$ & $\begin{array}{l}\text { Advanced } \\
\text { weathered } \\
\text { lava }\end{array}$ & $\begin{array}{c}\text { Most } \\
\text { weathered lava }\end{array}$ & $\begin{array}{l}\text {-Volcano-tectonic map of } \\
\text { Ngazidja Island (1/50 000) }\end{array}$ \\
\hline (b) & - & High rocky cliff & $\begin{array}{l}\text { Medium rocky } \\
\text { cliff }\end{array}$ & $\begin{array}{l}\text { Low rocky } \\
\text { cliff }\end{array}$ & $\begin{array}{l}\text { Unlithified } \\
\text { rocky cliff }\end{array}$ & Beach & $\begin{array}{l}\text { - Field surveys } \\
\text { - Aerial high-resolution } \\
\text { photographs from } 2018 \text { (1 dpi) }\end{array}$ \\
\hline (c) & M & $>75$ & $75-51$ & $50-31$ & $30-11$ & $0-10$ & $\begin{array}{l}\text { - SRTM (30 m) } \\
\text { (http://glovis.usgs.gov/) }\end{array}$ \\
\hline (d) & $\mathrm{m} / \mathrm{yr}$ & $\geq 2$ & $2-1$ & $0.9-0.1$ & $0--0.9$ & $\leq-1.0$ & $\begin{array}{l}\text { - Landsat TM1989 and OLI } 219 \\
\text { (http://glovis.usgs.gov/) }\end{array}$ \\
\hline (e) & - & Very calm & Sheltered & Semi-exposed & Exposed & Fully exposed & $\begin{array}{l}\text { - Field surveys } \\
\text { - Aerial high-resolution } \\
\text { photographs from } 2018 \text { (1 dpi) }\end{array}$ \\
\hline (f) & $\mathrm{mm} / \mathrm{yr}$ & $0.5-0.9$ & $1-1.9$ & $2-3.9$ & $4-5$ & $>5$ & - (Cazenave et al. 2015) \\
\hline (g) & $\mathrm{m}$ & $0-1$ & $1-2$ & $2-3$ & $3-4$ & $>4$ & - (Mahabot and Dev 2015) \\
\hline (h) & $\mathrm{m}$ & $<1$ & $1-2$ & $2.1-3$ & $3.1-4.9$ & $>4.9$ & $\begin{array}{l}\text { - French Navy's Hydrographic } \\
\text { and Oceanographic Department } \\
\text { (SHOM) } \\
\text { - (Sinane et al. 2011) }\end{array}$ \\
\hline (i) & - & Bare rocks & $\begin{array}{l}\text { Grassy and } \\
\text { shrub } \\
\text { formations }\end{array}$ & Farm field & Village & City & $\begin{array}{l}\text { - Feld surveys } \\
\text { - Aerial high-resolution } \\
\text { photographs from } 2018 \text { (1 dpi) }\end{array}$ \\
\hline
\end{tabular}

\section{Figures}




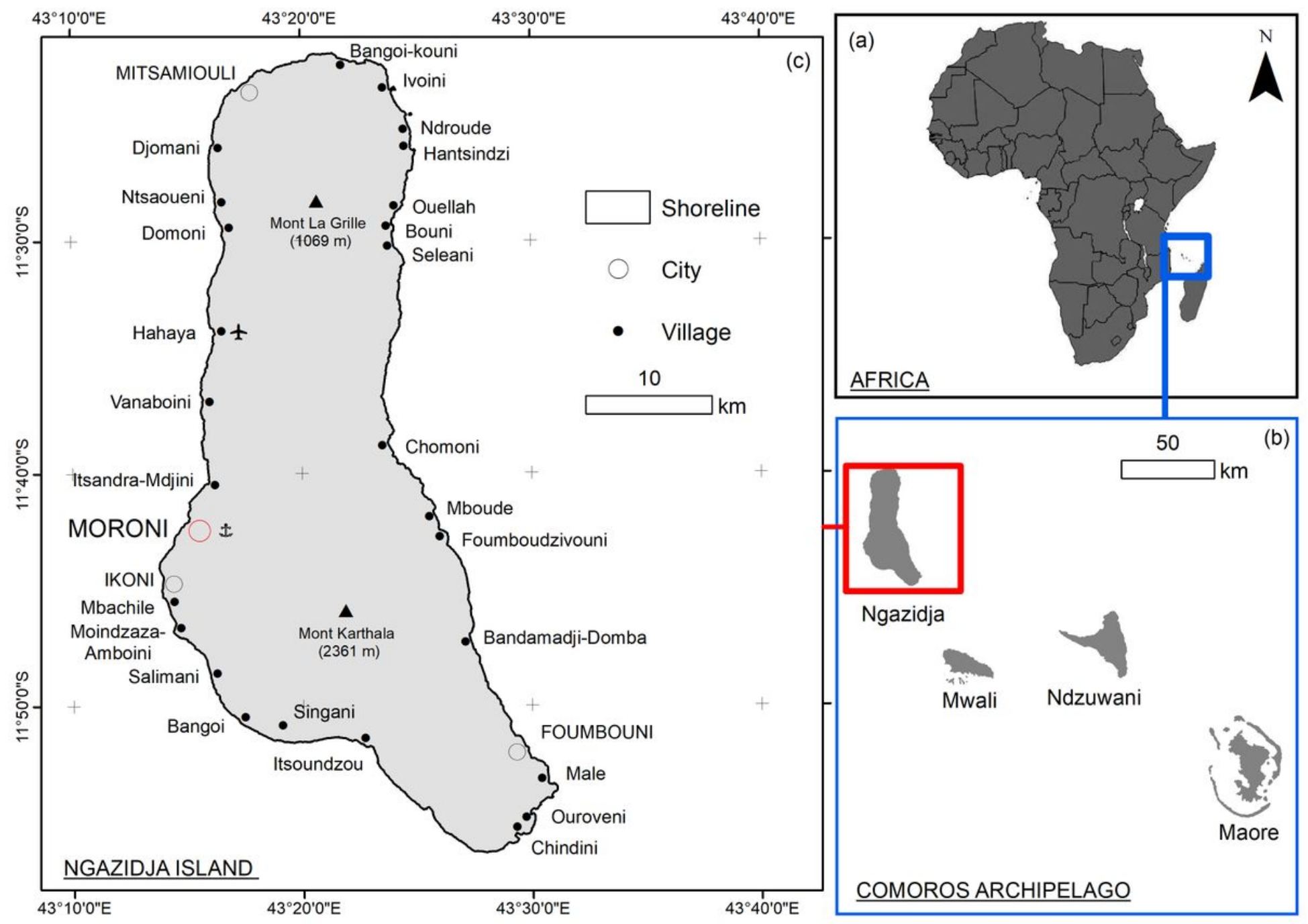

Figure 1

Map of the study area: Location of the Comoros archipelago (a), Islands of the Comoros archipelago (b) and, Ngazidja Island (c). 


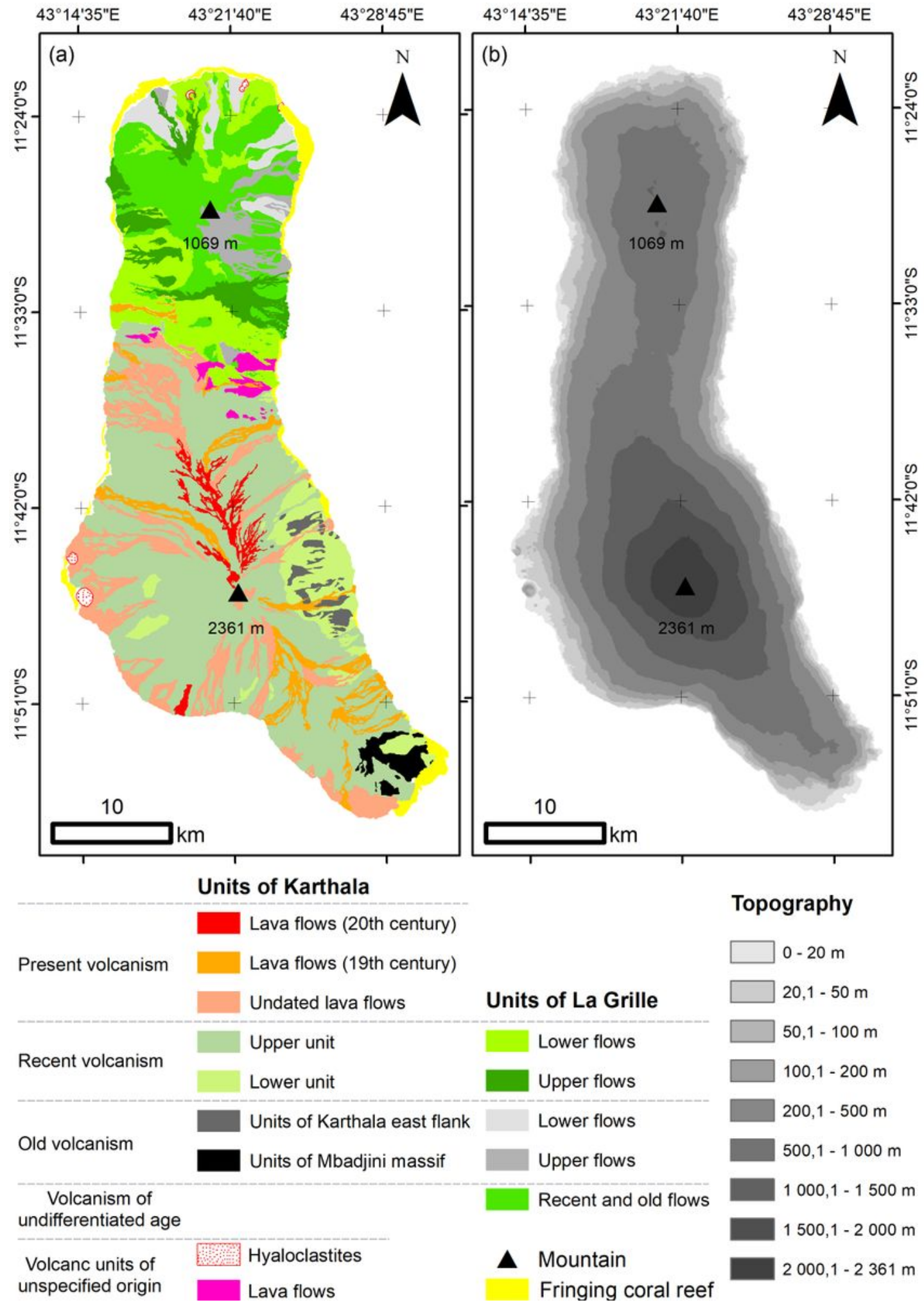

\section{Figure 2}

Simplified volcanological map of Ngazidja Island (Bachèlery and Coudray 1993) (a) / Topography of Ngazidja Island from SRTM (http://glovis.usgs.gov/) (b). 
(a) Coastal geology

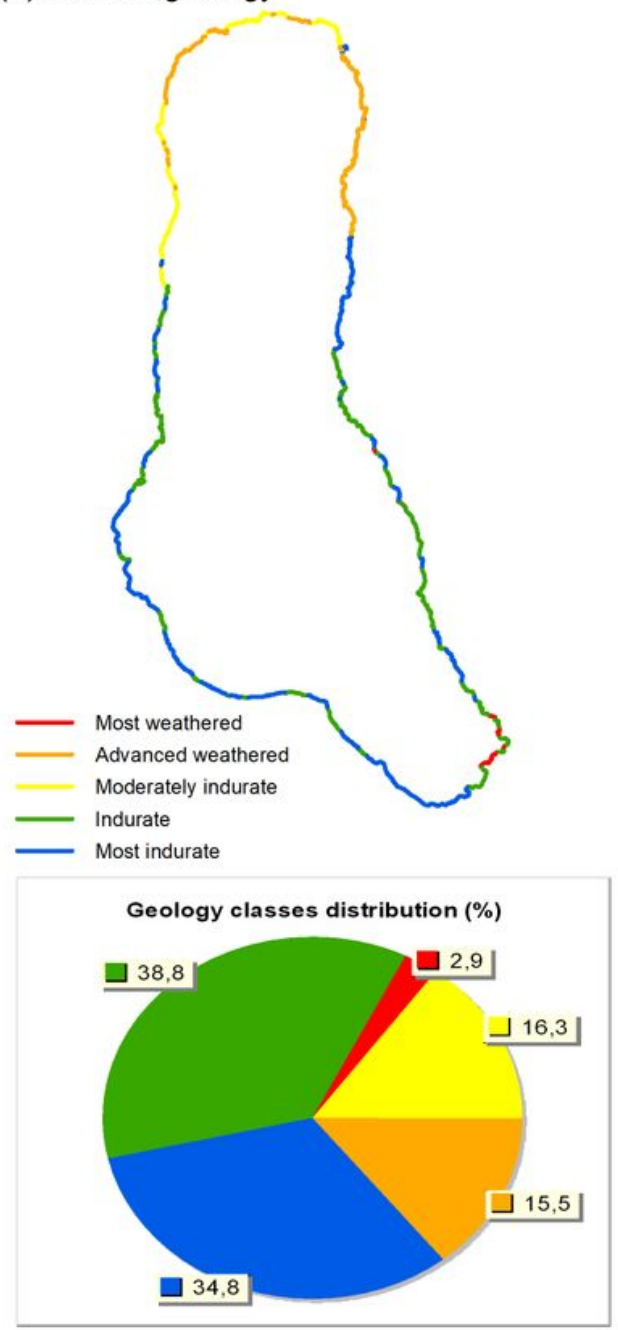

(b) Coastal geomorphology

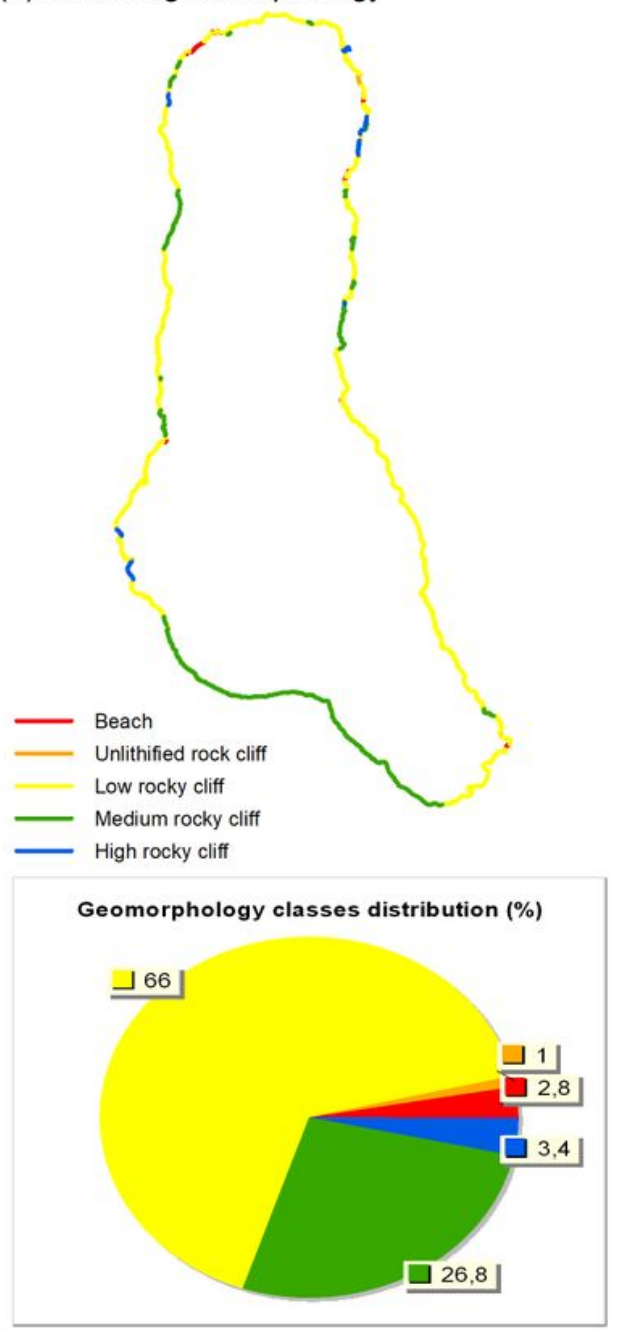

(c) Coastal topography

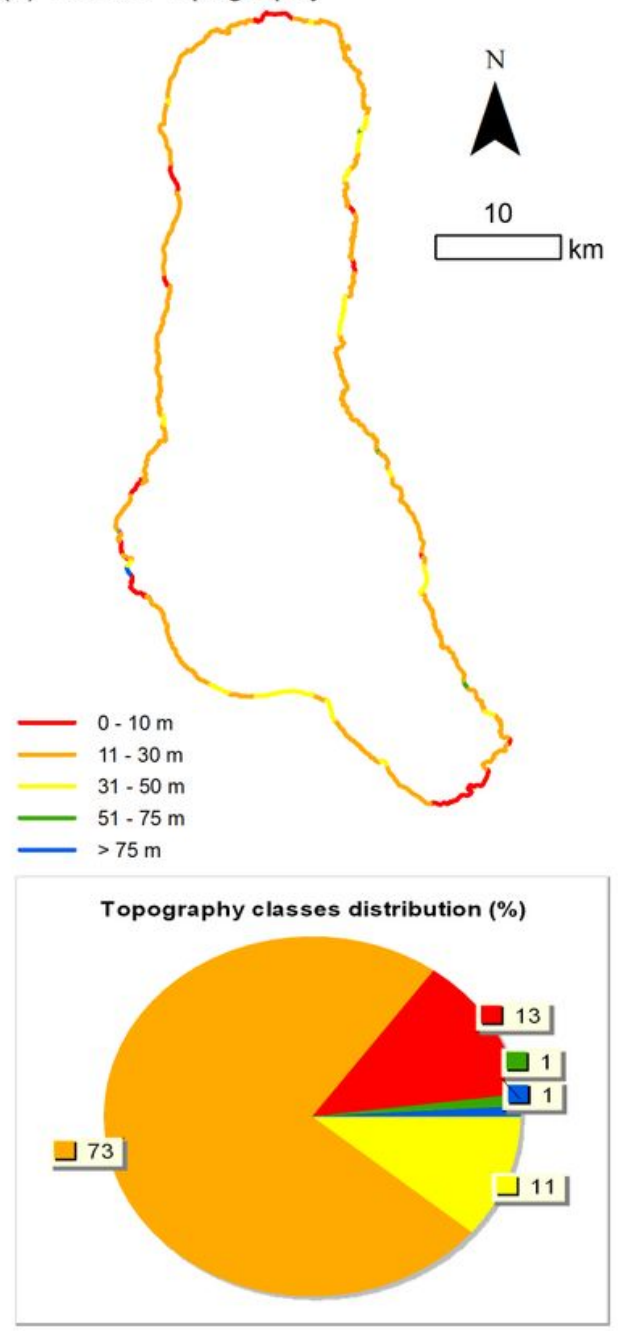

\section{Figure 3}

The relative ranking and spatial distribution of geology (a), geomorphology (b), and topography (c) of Ngazidja Island coastline. 
(d) Shoreline change

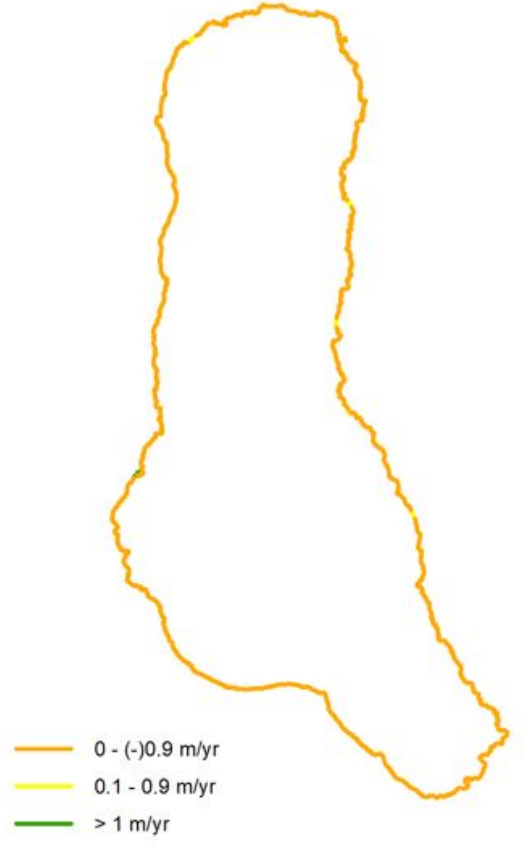

Shoreline change classes distribution (\%)

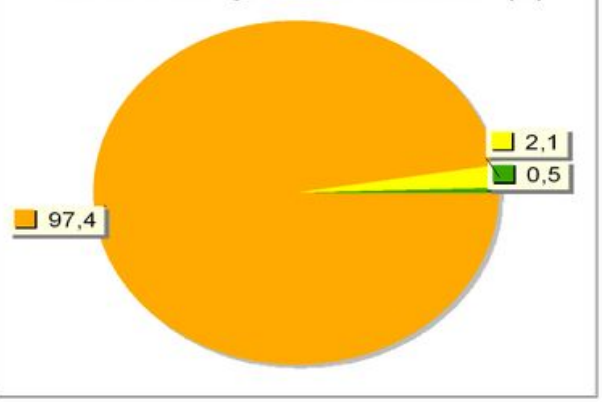

(e) Shoreline exposure

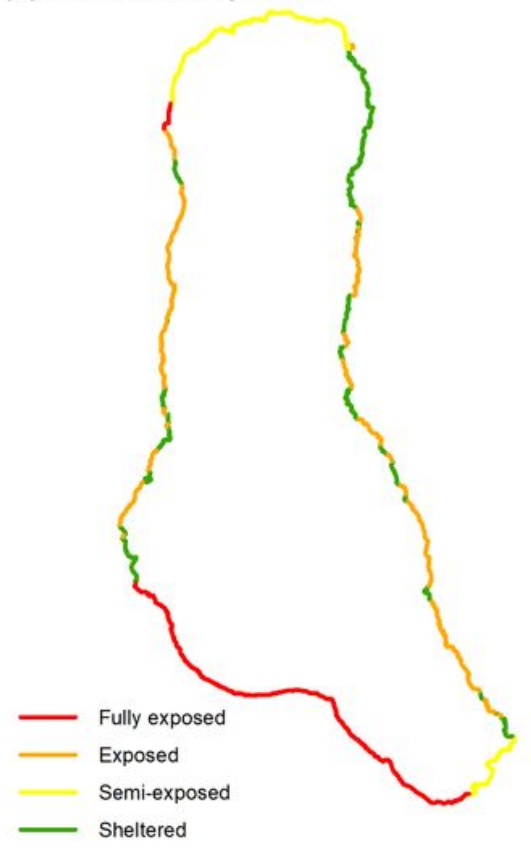

Shoreline exposure classes distribution (\%)

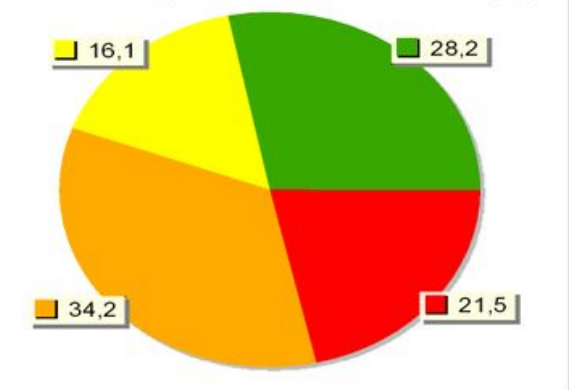

(f) Sea-level rise

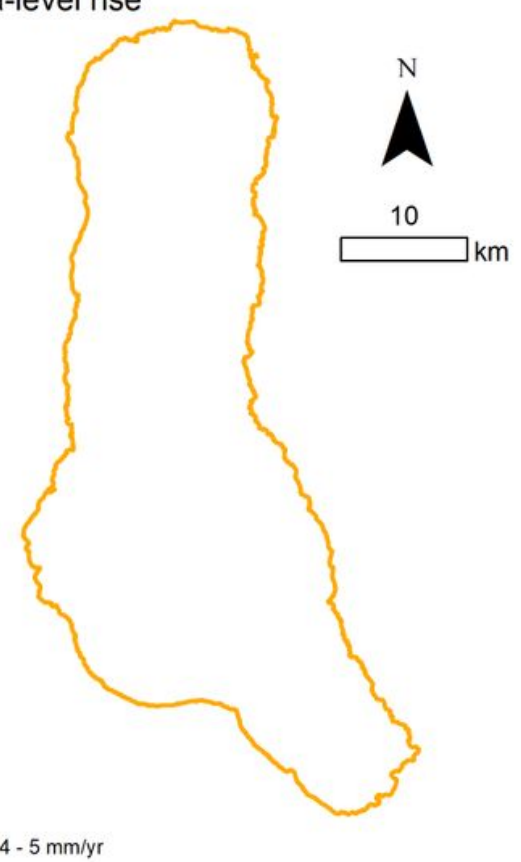

Sea level rise class distribution (\%)

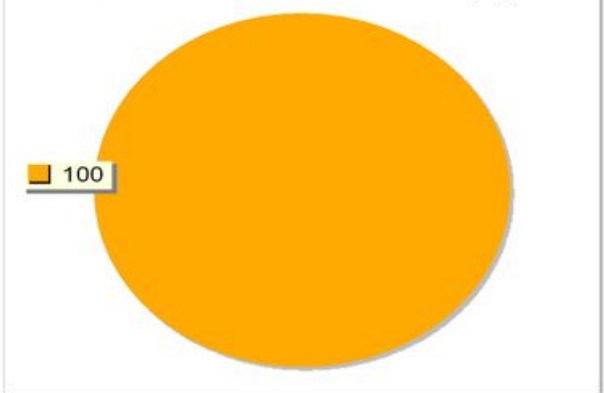

\section{Figure 4}

The relative ranking and spatial distribution of shoreline change (d), shoreline exposure (e), and relative sea-level rise (f) of Ngazidja Island coastline. 
(a)

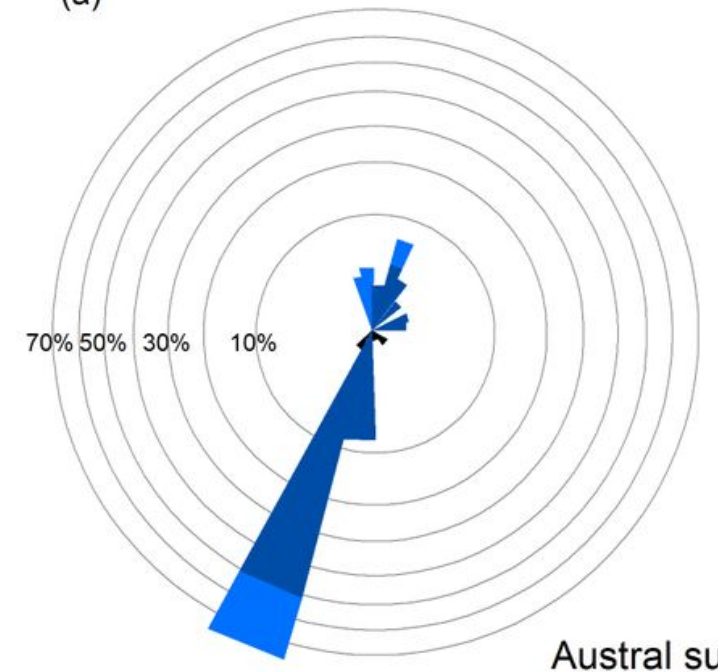

(b)

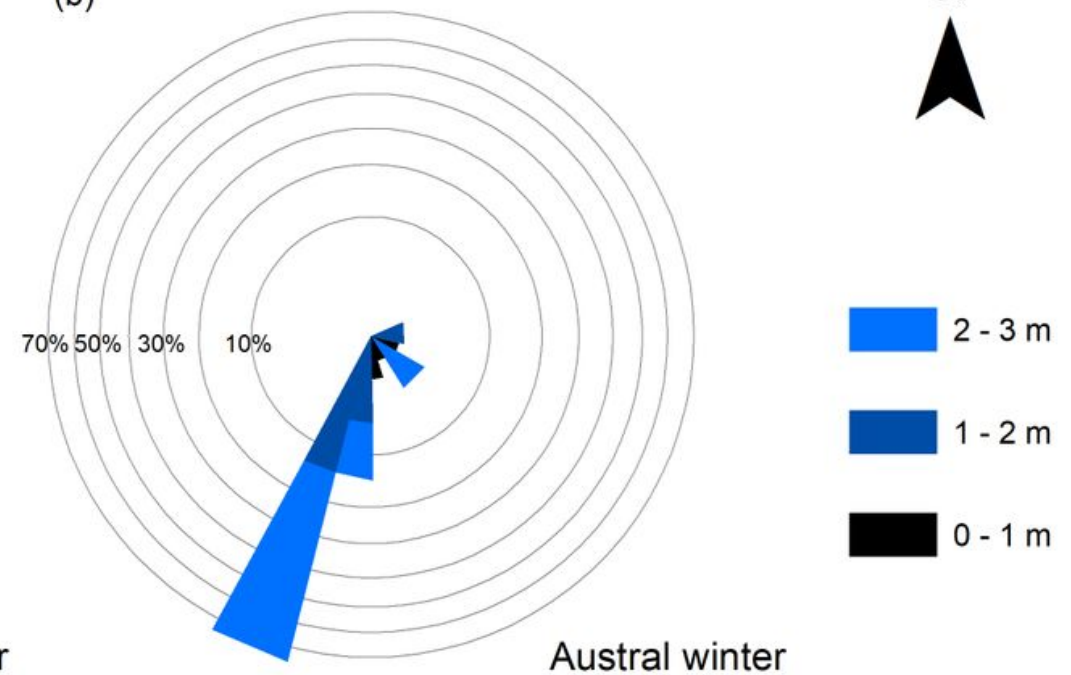

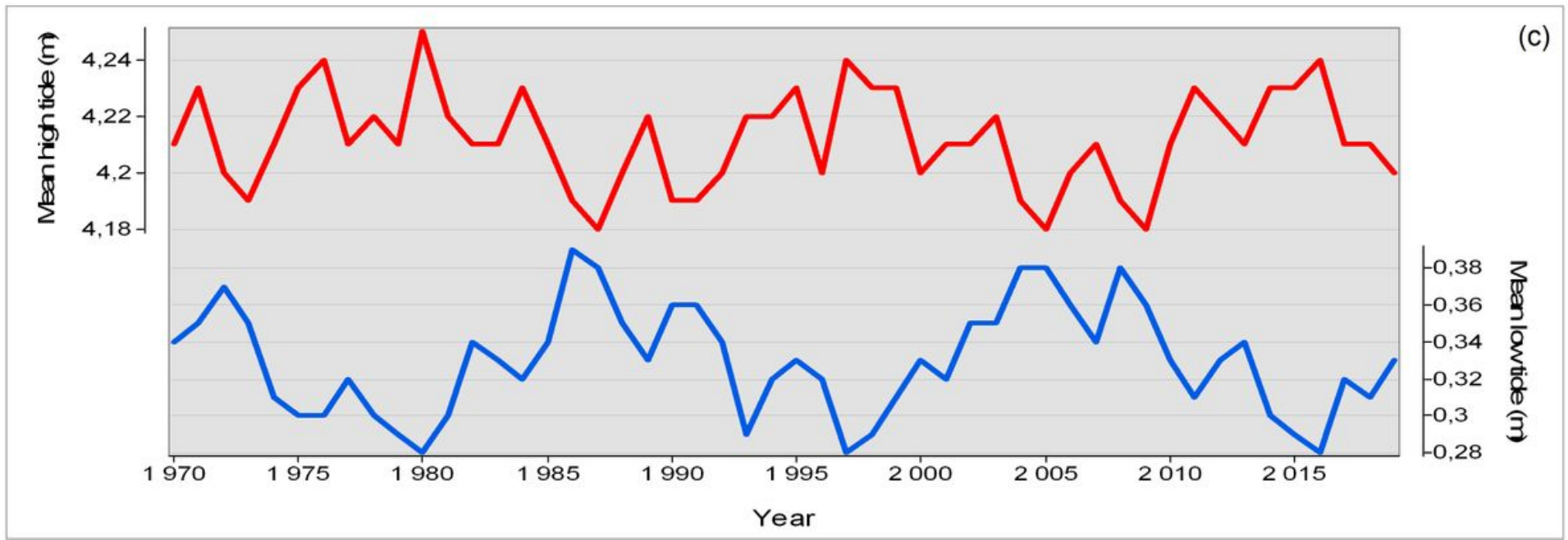

Figure 5

Mean significant wave heights rose in austral summer (a) and austral winter (b) (Reading direction of the swell direction from the outside to the inside) (Mahabot and Dev 2015) / Mean water levels at low and high tide noticed at the Moroni Port station over 1970 - 2019 (c). 
(g) Significant wave height

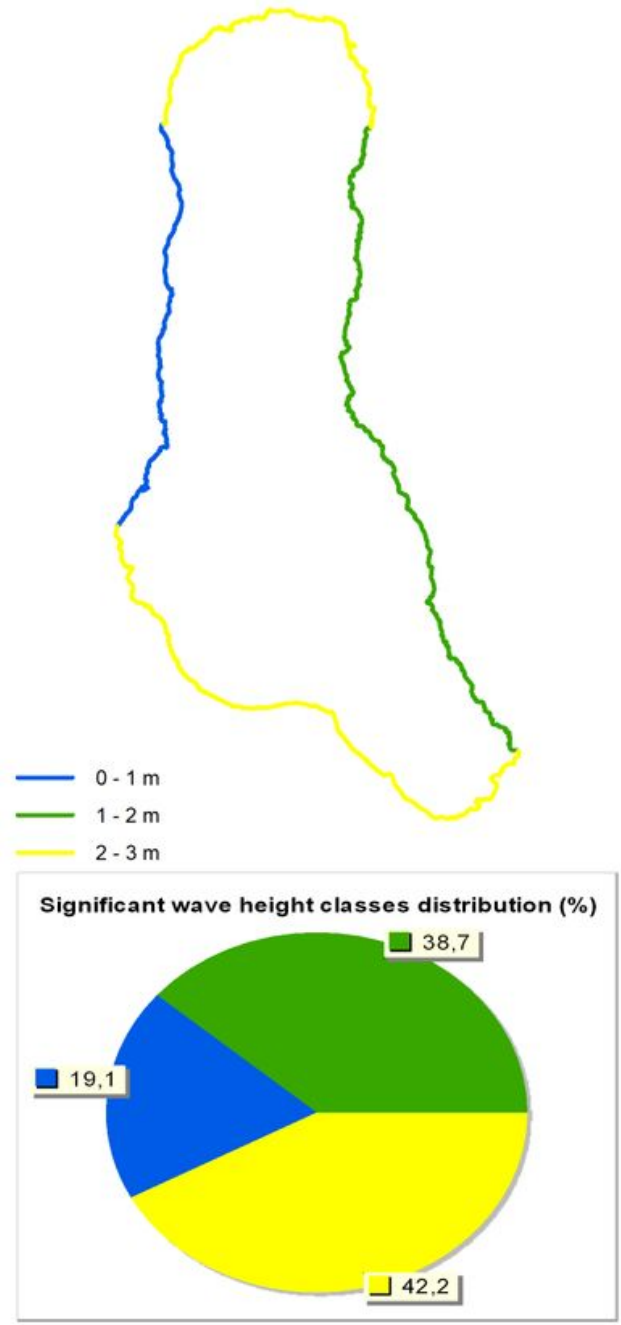

(h) Mean tide range
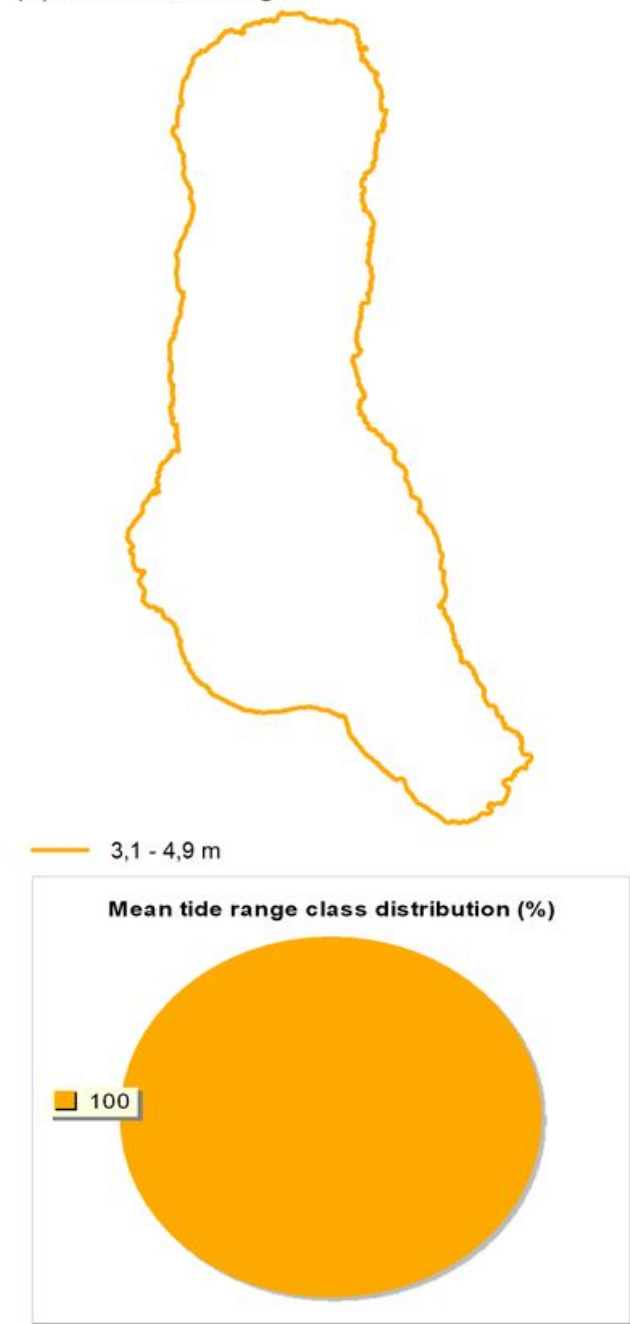

(i) Land use

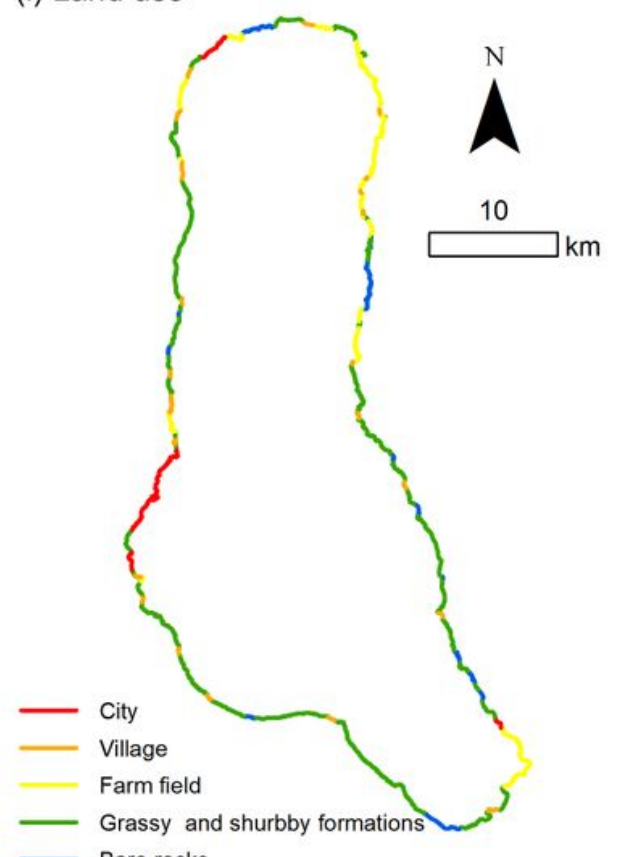

Bare rocks

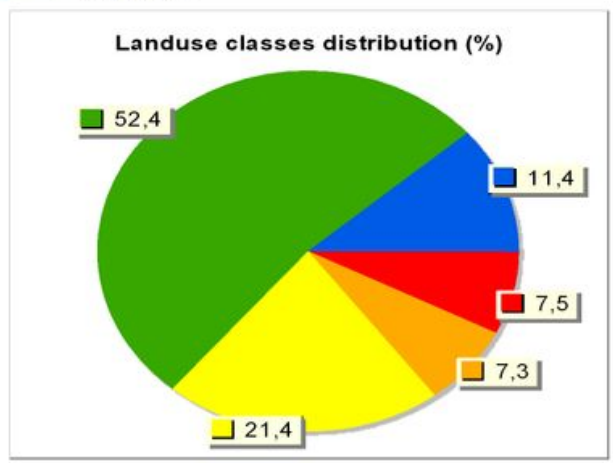

\section{Figure 6}

The relative ranking and spatial distribution of the mean significant wave height $(\mathrm{g})$, tide range $(\mathrm{h})$, and land-use of Ngazidja Island (i). 


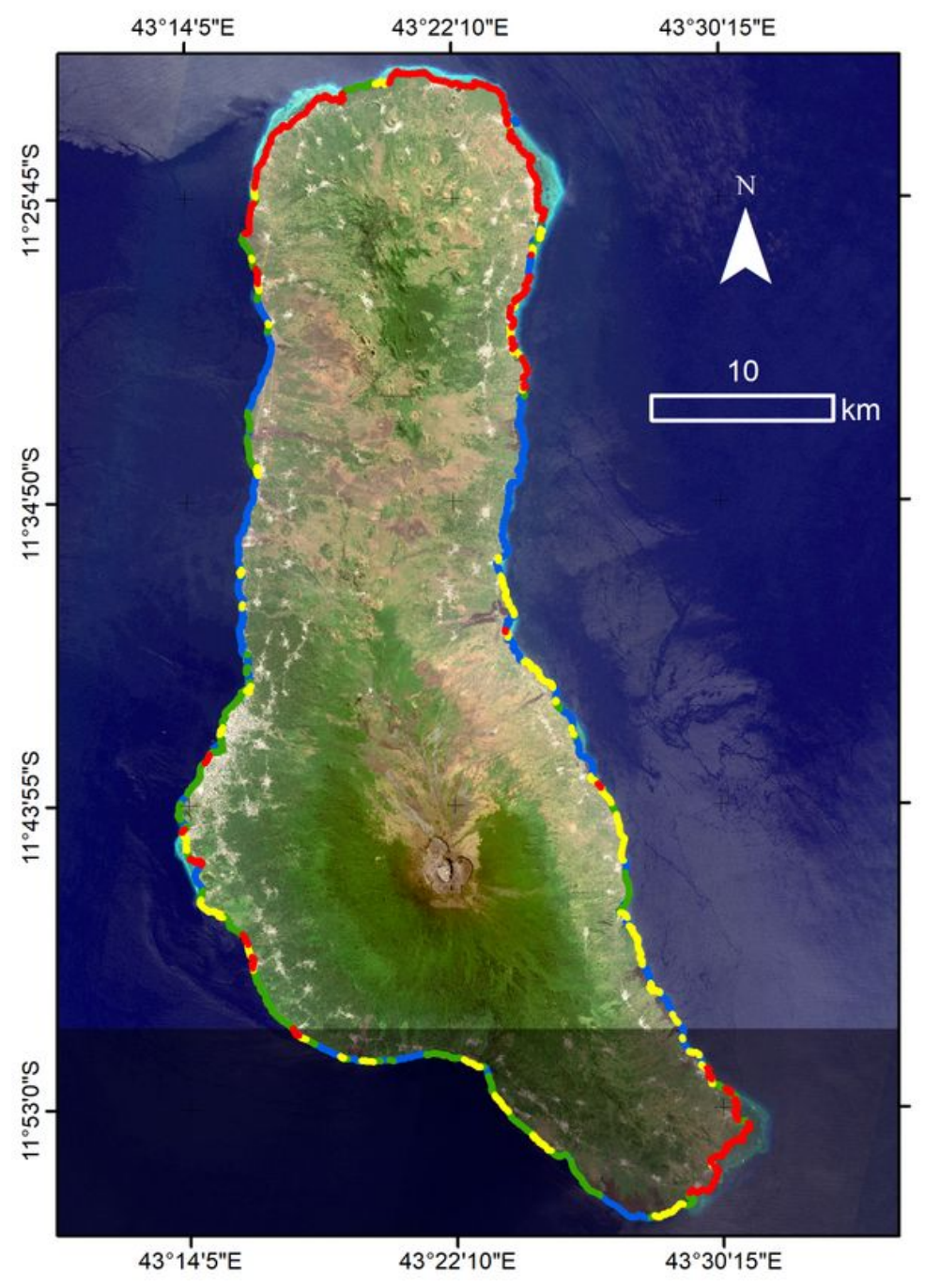

\section{Statistical classification}

\begin{tabular}{|c|c|}
\hline Very high & [58.5 - 160] \\
\hline High & [51.4 - 58.4] \\
\hline Moderate & [37.1 - 51.3] \\
\hline Low & [9.2 - 37] \\
\hline
\end{tabular}

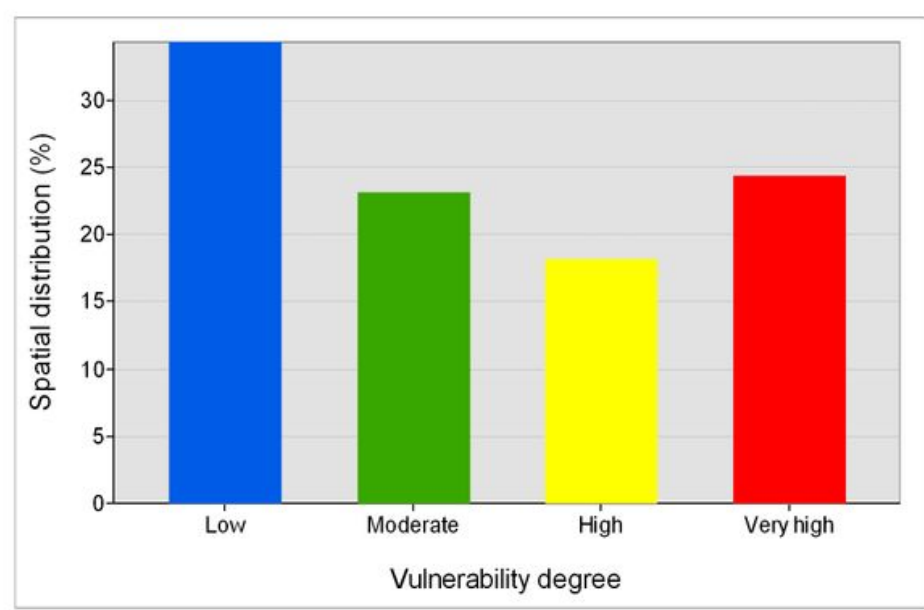

\section{Figure 7}

Map of Ranking of Coastal Vulnerability Index values of Ngazidja Island coastline. 

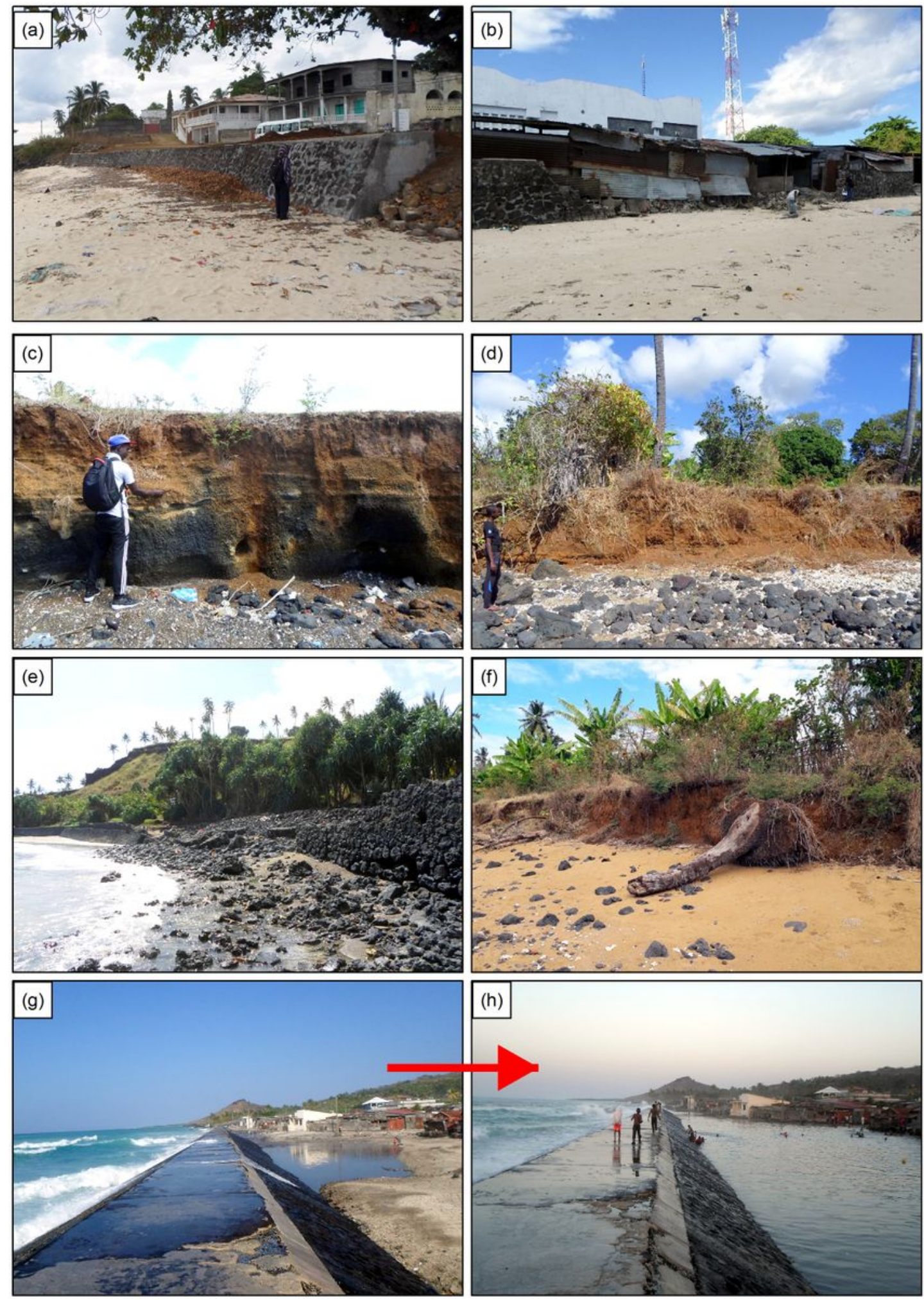

\section{Figure 8}

Coastal flood and erosion indicators: New seawall (a) and collapse of protective wall (b) on the upper beach of Mitsamiouli, Active cliffs on Male (volcanic slags) (c) and Ndroude (alluvium of pyroclastic materials) shores (d), Erosion at the foot of protective wall on Mbachile shore (e), Vegetation degradation on Ndroude shore (f), and coastal inundation on Bangoi-kouni shore on August 12, 2018 ( $\mathrm{g}$ and $\mathrm{h}$ ). 